\title{
ANALISIS EFEKTIVITAS PENYALURAN DANA ZAKAT, INFAK DAN SEDEKAH PADA YAYASAN RUMAH ZAKAT
}

\author{
Ahmad Yudhira, SE, Ak, M.Si \\ Fakultas Ekonomi Universitas Tjut Nyak Dhien, Program Studi Akuntansi \\ Email: ahmadyudhiraMSC@ gmail.com
}

\begin{abstract}
This study aims to determine the effectiveness of the distribution of funds (use of assets) at the Rumah Zakat Foundation by using the allocation to collection ratio (ACR). This research uses a combination of qualitative and quantitative methods. The research data was obtained by taking the publication of the financial statements of the zakat house foundation in 2018. Based on the results of the study it was concluded that the distribution of funds (use of assets) at the Rumah Zakat Foundation using the allocation to collection ratio (ACR) was very effective. Gross Allocation to Collection Ratio of 0.892 (89.17\%); Gross allocation to non-amil collection ratio of 0.874 (87.40\%); Net Allocation to collection Ratio of 0.997 (99.71\%); net Allocation to non-amil collection for 0.997 (99.66\%).
\end{abstract}

Keywords: Effectiveness, zakat, donation, alms, Rumah zakat

\begin{abstract}
Abstrak
Penelitian ini bertujuan untuk mengetahui. Sejauh mana efektivitas penyaluran dana (penggunaan asset) pada Yayasan Rumah Zakat dengan menggunakan allocation to collection ratio (ACR). Penelitian ini menggunakan metode penggabungan antara metode kualitatif dan kuantitatif. Data penelitian diperoleh dengan mengambil publikasi laporan keuangan yayasan rumah zakat pada tahun 2018. Berdasarkan hasil penelitian disimpulkan bahwa penyaluran dana (penggunaan asset) Pada Yayasan Rumah Zakat dengan menggunakan allocation to collection ratio (ACR) adalah sangat efektif. Gross Allocation to Collection Ratio sebesar 0,892 (89,17\%); Gross allocation to collection ratio non amil sebesar 0,874 (87,40\%); Net Allocation to collection Ratio sebesar 0,997 $(99,71 \%) ;$ net Allocation to collection non amil sebesar 0,997 (99.66\%).
\end{abstract}

Kata Kunci: Efekti vitas, zakat, infak, sedekah, rumah zakat

\section{Pendahuluan}

Zakat merupakan salah satu rukun Islam yang telah diwajibkan oleh Allah SWT kepada setiap muslim. Penyebutan zakat dalam Al-Qur'an sering mengiringi penyebutan shalat agar kita tidak hanya memperhatikan hak Allah saja, tapi juga memperhatikan hak sesama manusia. Sebagai muslim, kita wajib mempelajari ilmu mengenai zakat agar dapat menjalankannya dengan benar, sama halnya kewajiban untuk mempelajari bagaimana rukun dan syarat menjalankan ibadah shalat serta rukun Islam lainnya. Kewajiban zakat ini diturunkan bertujuan untuk mengentaskan kemiskinan, karena sasaran utama zakat adalah untuk mencukupi kebutuhan orang-orang fakir dan miskin. Sedangkan tujuan Pengelolaan Zakat menurut Undang-Undang Nomor 23 Tahun 
2011 ialah: (1) meningkatkan efektivitas dan efisiensi pelayanan dalam pengelolaan zakat, dan (2) meningkatkan manfaat zakat untuk mewujudkan kesejahteraan masyarakat dan penanggulangan kemiskinan.

Diantara esensi pengelolaan zakat melalui institusi amil adalah bagaimana mengefektifkan program penyaluran zakat yang memiliki dampak positif terhadap kesejahteraan mustahik (kelompok penerima zakat). kualitas program penyaluran zakat harus terus ditingkatkan. Badan Amil zakat wajib meningkatkan kapasitasnya dalam menyalurkan zakat, baik untuk programprogram yang bersifat konsumtif dalam jangka pendek, maupun untuk programprogram yang bersifat produktif, memberdayakan, dan memiliki dampak pada jangka panjang.

Berdasarkan dokumen Zakat Core Principles (ZCP) dalam Beik (2016), Kepala Pusat Studi Bisnis dan Ekonomi Syariah (CIBEST) IPB mengatakan telah disepakati dalam empat kali pertemuan International Working Group on Zakat Core Principles yang dihadiri perwakilan 11 (sebelas) negara, telah dinyatakan tentang pentingnya program penyaluran zakat. Dokumen tersebut menggarisbawahi bahwa kualitas penyaluran zakat dapat dilihat dari tiga aspek yaitu dari sisi rasio keuangan zakat yang dikelola oleh lembaga zakat resmi. Dokumen ZCP memperkenalkan konsep ACR (Allocation to Collection Ratio). ACR ini adalah rasio perbandingan antara proporsi dana zakat yang disalurkan dengan dana zakat yang dihimpun. Dalam dokumen tersebut diungkap lima kategori nilai ACR ini, yaitu kategori highly effective (>90\%), effective (70\%-89\%), fairly effective (50\%$69 \%$ ), below expectation (20\%-49\%), dan ineffective $(<20 \%)$.

1. Kategori pertama menunjukkan proporsi dana zakat yang disalurkan lebih dari $90 \%$ dibandingkan dengan dana zakat yang diterima. Hak amil yang digunakan kurang dari 10\%. Ini menunjukkan bahwa lembaga zakat memiliki kapasitas penghimpunan dan penyaluran yang sangat besar. Adapun pada kategori kedua, proporsi penyaluran zakat dibandingkan dengan penghimpunannya berkisar diantara $70 \%$ hingga $89 \%$. Hal ini menunjukkan hak amil yang digunakan mencapai angka $11 \%$ hingga $30 \%$, demikian seterusnya. Semakin besar penggunaan proporsi hak amil, maka semakin rendah kapasitas penghimpunan dan penyaluran suatu lembaga zakat, sehingga tingkat efektivitas program 
penyaluran zakat menjadi semakin rendah.

2. Aspek kedua adalah kecepatan penyaluran zakat. Dokumen ZCP membagi aspek kecepatan penyaluran zakat ini ke dalam dua kategori, yaitu kategori program konsumtif dan kategori program produktif. Program konsumtif adalah program yang didesain untuk memenuhi kebutuhan mustahik pada jangka pendek seperti program bantuan pangan dan kesehatan, sedangkan program produktif adalah program yang didesain untuk memenuhi kebutuhan mustahik pada jangka panjang, seperti program pendidikan dan ekonomi. Dalam program konsumtif, indikator program penyaluran yang efektif adalah ketika program tersebut dieksekusi kurang dari 3 (tiga) bulan sejak diputuskan secara resmi oleh manajemen lembaga zakat. Dokumen ZCP menyebutnya dengan istilah fast. Apabila penyalurannya antara 3-6 bulan, maka disebut good. Selanjutnya, 6-9 bulan disebut fair, 9-12 bulan disebut slow, dan lebih dari 12 bulan extremely slow. Artinya, semakin lama kecepatan penyalurannya, maka semakin rendah kapasitas penyaluran zakat, sehingga semakin tidak efektif program konsumtif yang dilakukan. Sementara dalam program produktif, klasifikasi kecepatan penyalurannya terbagi menjadi tiga. Yaitu, fast (kurang dari 6 bulan), good (6-12 bulan) dan fair (lebih dari 12 bulan). Hal yang perlu diperhatikan adalah bahwa jangka waktu tersebut bukan menunjukkan lamanya program, karena program bisa bersifat multiyears, akan tetapi kecepatan untuk mulai mengeksekusi program pasca penetapan keputusan oleh pimpinan atau manajemen lembaga zakat.

3. Aspek ketiga adalah manajemen risiko penyaluran zakat. Dalam konteks ini, dokumen ZCP telah menetapkan dua hal penting yang perlu diperhatikan dalam mengelola risiko penyaluran zakat. Yaitu, memenuhi kewajiban finansial secara tepat waktu dan melakukan antisipasi jika terjadi mismatch antara alokasi dana dengan kebutuhan riil yang diperlukan untuk berjalannya suatu program. Pada sisi kewajiban keuangan, setiap keterlambatan berpotensi menimbulkan dampak negatif bagi mustahik. Misalnya, keterlambatan penyaluran dana beasiswa berpotensi mengancam keberlangsungan pendidikan mustahik. 
Adapun pada sisi mismatch, ketidaksinkronan antara dana yang dialokasikan dengan kebutuhan riil program menunjukkan kekurangprofesionalan lembaga zakat sehingga berpotensi menciptakan kegagalan program penyaluran. Oleh karena itu, diperlukan adanya mitigasi resiko ini sehingga mustahik tidak terkena imbas negatifnya. Disinilah pentingnya peningkatan kualitas perencanaan dan pengorganisasian lembaga zakat sehingga program penyaluran yang dilakukannya dapat berjalan efektif dan memenuhi ekspektasi publik.

Menurut Undang-Undang No 23 Tahun 2011 tentang Pengelolaan Zakat, ada dua lembaga yang memiliki tugas untuk mengelola, mendistribusikan, dan mendayagunaan zakat, yaitu Badan Amil Zakat Nasional (BAZNAS) dan Lembaga Amil Zakat (LAZ). BAZNAS merupakan lembaga yang dibentuk oleh pemerintah pusat untuk melakukan tugas pengelolaan zakat secara nasional. Secara kelembagaan bersifat mandiri, non struktural, berkedudukan di Jakarta dan bertanggung jawab kepada Presiden melalui Menteri Agama. LAZ merupakan lembaga pengelola zakat yang dibentuk atas inisiatif dari masyarakat. Sampai saat ini ada 17 LAZ skala nasional yang telah mendapatkan Ijin dari Kementerian Agama, diantaranya NU CARE LAZISNU (lembaga amil zakat di bawah naungan NU), LAZISMU (lembaga amil zakat di bawah naungan Muhammadiyah), Dompet Dhuafa, DT Peduli, Rumah Zakat dan lain-lain.

Berdasarkan penjabaran di atas, maka peneliti tertarik untuk membahas tentang analisis efektivitas penyaluran dana zakat, infak dan sedekah pada Yayasan Rumah Zakat dengan menggunakan allocation to collection ratio (ACR).

\section{Tinjauan Pustaka}

\subsection{Konsep Zakat}

Menurut bahasa, zakat artinya tumbuh dan berkembang, atau menyucikan karena zakat akan mengembangkan pahala pelakunya dan membersihkannya dari dosa. Menurut syariat, zakat ialah hak wajib dari harta tertentu pada waktu tertentu (Mu'is, 2011). Selain itu zakat adalah ibadah dan kewajiban sosial bagi para aghniya' (hartawan) setelah kekayaannya memenuhi batas minimal (nishab) dan rentang waktu setahun (haul). Tujuannya untuk mewujudkan pemerataan keadilan dalam ekonomi.

Menurut BAZNAS (2018), secara umum zakat terbagi atas dua yaitu zakat 
fitrah dan zakat harta. Berikut adalah penjelasannya:

\section{1) Zakat Fitrah}

Zakat fitrah adalah zakat yang wajib ditunaikan bagi seorang muslim/ah yang sudah mampu untuk menunaikannya. Zakat fitrah harus dikeluarkan setahun sekali pada saat awal bulan Ramadhan hingga batas sebelum sholat hari raya Idul Fitri. Hal tersebut yang menjadi pembeda zakat fitrah dengan zakat lainnya. Sebagaimana tercantum pada hadits Rasulullah SAW yatu: "Barangsiapa yang menunaikan zakat fitri sebelum shalat Id maka zakatnya diterima dan barangsiapa yang menunaikannya setelah shalat Id maka itu hanya dianggap sebagai sedekah di antara berbagai sedekah" (H.R. Abu Daud). Zakat fitrah ditunaikan dalam bentuk beras atau makanan pokok seberat 2,5 $\mathrm{kg}$ atau 3,5 liter per jiwa. Kualitas beras atau makanan pokok harus sesuai dengan kualitas beras atau makanan pokok yang dikonsumsi kita sehari-hari. Namun, beras atau makanan pokok tersebut dapat diganti dalam bentuk uang senilai 2,5 $\mathrm{kg}$ atau 3,5 liter beras.

\section{2) Zakat Harta}

Menurut bahasa, harta adalah segala sesuatu yang diinginkan sekali oleh manusia untuk memiliki, memanfaatkan dan menyimpannya. Sedangkan menurut istilah, harta adalah segala sesuatu yang dapat dimiliki (dikuasai) dan dapat digunakan (dimanfaatkan). Sesuatu dapat disebut dengan maal (harta) apabila memenuhi 2 (dua) syarat, yaitu:

- Dapat dimiliki, disimpan, dihimpun, dikuasai.

- Dapat diambil manfaatnya sesuai dengan ghalibnya. Misalnya: rumah, mobil, ternak, hasil pertanian, uang, emas, perak, dan lain-lain.

Syarat harta yang wajib di zakati yaitu, milik penuh, bertambah atau berkembang, cukup nisab, lebih dari kebutuhan pokok, bebas dari hutang, dan sudah berlalu satu tahun (haul).

Menurut BAZNAS (2018), zakat maal (harta) dibagi dalam beberapa jenis:

\section{Zakat Penghasilan}

Zakat penghasilan atau zakat profesi wajib dikeluarkan atas harta yang berasal dari pendapatan rutin dari pekerjaan yang tidak melanggar syariah, Peraturan Menteri Agama No 52/2014, dan pendapat Syekh Yusuf Qardawi. 
Standar nisab yang digunakan adalah sebesar Rp5.240.000 per bulan. Cara menghitung zakat penghasilan adalah jumlah pendapatan bruto x 2,5\%. Jika penghasilan Rp6 juta/bulan maka zakatnya Rp6 juta x 2,5\% = Rp150.000.

\section{Zakat Emas dan Perak}

Zakat emas, perak dan logam mulia ditunaikan jika telah mencapai nisab dan haul senilai 85 gram atau perak dengan mencapai nisab 595 gram. Tarif zakat yang harus dibayarkan adalah sebesar 2,5\% dari emas atau perak yang dimiliki. Cara menghitung zakat emas/perak adalah 2,5\% x jumlah emas/perak yang tersimpan selama 1 tahun.

Jika seseorang selama setahun memiliki emas 100 gram dengan harga rata-rata Rp622 ribu/gram, maka zakatnya 2,5\% $\mathrm{x} \operatorname{Rp} 62,2$ juta $=\operatorname{Rp} 1.555 .000$.

\section{Zakat Perdagangan}

Zakat perdagangan adalah zakat dari harta niaga. Harta niaga adalah harta atau aset yang dijualbelikan dengan maksud mendapatkan keuntungan. Harta perdagangan yang dikenakan zakat dihitung dari aset lancar usaha yang sudah mencapai setahun dikurangi utang jangka pendek yang jatuh tempo satu tahun. Jika selisihnya aset lancar dan utang tersebut sudah mencapai nisab 85 gram emas, maka wajib dibayarkan zakatnya. Cara menghitung zakat perdagangan adalah 2,5\% x (aset lancar - utang jangka pendek). Jika kita mempunyai aset usaha Rp200 juta dan utang jangka pendek Rp50 juta, maka selisihnya sudah lebih dari nisab 85 gram emas yang setara uang $\mathrm{Rp}$ 52.870.000, maka perhitungan zakatnya 2,5\% x (Rp200 juta - Rp50 juta $)=$ Rp3.750.000.

\section{Zakat Perusahaan}

Para ulama dalam Muktamar Internasional Pertama tentang zakat di Kuwait (29 Rajab 1404 H), menganalogikan zakat perusahaan kepada zakat perdagangan. Oleh karena itu, secara umum cara menghitung zakat perusahaan dianggap sama dengan zakat perdagangan begitu pun dengan kadar nisabnya setara dengan 85 gram emas. Sebuah perusahaan biasanya memiliki harta yang tidak akan terlepas dari tiga bentuk: Pertama, harta dalam bentuk barang, baik yang berupa sarana dan prasarana maupun yang merupakan komoditas perdagangan. Kedua, harta dalam bentuk uang tunai yang biasanya disimpan di bank-bank. Ketiga, harta 
dalam bentuk piutang. Harta perusahaan yang harus dizakati adalah harta barang, uang tunai dan piutang, dikurangi harta dalam bentuk sarana dan prasarana serta dikurangi kewajiban mendesak seperti utang yang jatuh tempo atau yang harus dibayar saat itu juga. Cara menghitung zakat perusahaan adalah 2,5\% x (Aset Lancar - Utang Jangka Pendek). Jika perusahaan mempunyai aset Rp2 miliar dan utang Rp500 juta maka zakat yang perlu ditunaikan adalah 2,5\% x (Rp2 miliar - Rp500 juta) $=$ Rp37,5 juta.

\section{Zakat Saham}

Zakat saham ditetapkan para ulama pada Muktamar Internasional Pertama tentang zakat di Kuwait (29 Rajab 1404 H). Hasil dari keuntungan investasi saham wajib dikeluarkan zakatnya jika nilai keuntungan investasi dalam setahun mencapai nisab 85 gram emas. Cara menghitung zakat saham adalah $2,5 \% \mathrm{x}$ jumlah harta yang tersimpan selama 1 tahun. Untuk zakat saham dapat ditunaikan dalam bentuk saham. Contoh: dalam setahun punya aset Rp100 juta dan melebihi nisab 85 gram emas atau Rp52.870.000 maka dihitunglah zakatnya 2,5\% x Rp100 juta $=\mathrm{Rp} 2,5$ juta. Jika dikonversi dalam saham Rp2,5 juta : (nilai saham dalam satuan lot) = jumlah lot yang mesti dipindahkan sahamnya sebagai zakat.

\section{Zakat Reksadana}

Zakat reksadana ditetapkan para ulama pada Muktamar Internasional Pertama tentang zakat di Kuwait (29 Rajab 1404 H). Hasil dari keuntungan investasi wajib dikeluarkan zakatnya jika hasil keuntungan investasi dalam setahun sudah mencapai nisab 85 gram emas atau Rp52.870.000. Cara menghitung zakat reksadana adalah 2,5\% x Jumlah harta yang tersimpan selama 1 tahun.

Delapan golongan penerima zakat menurut Al-Qur'an surat At-Taubah ayat 60 yaitu:

1. Fakir: orang yang tidak punya penghasilan sehingga tidak bisa memenuhi kebutuhannya.

2. Miskin: orang yang memiliki harta atau pendapatan tapi masih belum bisa memenuhi semua kebutuhan hidupnya.

3. Amil: sekelompok orang yang memiliki tugas untuk mengurus urusan zakat. Dari mulai Mengumpulkan, mencatat, menyalurkan kepada orang yang berhak menerimanya.

4. Muallaf: orang-orang yang baru masuk islam dan dianggap imannya masih sangat lemah. Hamba Sahaya: seorang 
budak yang ingin membebaskan diri dari tuannya dengan membayar uang.

5. Gharimin: orang yang memiliki hutang namun tidak mampu untuk membayarnya karena sudah masuk ke golongan miskin.

6. Fisabilillah: orang yang sedang berjuang menegakan agama Allah seperti berdakwah ataupun berperang.

7. Ibnu Sabil: Orang yang dalam perjalanan dan kehabisan bekal, sehingga bisa meringannya dengan pemberian makanan agar terbebas dari kelaparan

\subsection{Pengelolaan dan pendistribusian} Zakat

Dalam konteks Al-Qur'an, pengelola zakat disebut amil. Amil zakat merupakan lembaga pengelola zakat yang dituntut bekerja secara profesional untuk dapat memanajemen pengelolaan zakat. Sehingga orang yang berhak menjadi amil adalah orang yang memenuhi syarat-syarat berikut: Muslim, Mukallaf (orang dewasa yang sehat akal dan pikirannya), Jujur (karena ia diamanati harta kaum muslimin), Memahami hukum-hukum zakat, Mampu melaksanakan tugas sebagai amil. Dalam pengelolaan zakat terdapat beberapa prinsip yang harus diikuti dan ditaati agar pengelolaan itu dapat berhasil guna sesuai dengan yang diharapkan, yakni prinsip keterbukaan, sukarela, keterpaduan, profesionalisme dan kemandirian (Djazuli, 2002).

Berdasarkan Undang-Undang Republik Indonesia Nomor 23 Tahun 2011 tentang Pengelolaan Zakat, yang dimaksud Pengelolaan Zakat adalah kegiatan perencanaan, pengorganisasian, pelaksanaan, dan pengawasan terhadap pengumpulan dan pendistribusian serta pendayagunaan zakat (Zuhri, 2014).

Menurut Qadratillah, et al (2011), pendistribusian adalah penyaluran/pembagian/ pengiriman barangbarang dan sebagainya kepada orang banyak atau beberapa tempat. Hal pertama dalam langkah pendistribusian zakat adalah dengan melakukan distribusi lokal atau lebih mengutamakan mustahiq dalam lingkungan terdekat dengan lembaga zakat dibandingkan pendistribusian untuk wilayah lainnya, hal itu dikenal dengan sebutan 'centralistic'. Kelebihan sistem centralistic dalam pengalokasian zakat adalah memudahkan penditribusiannya ke setiap provinsi. Hampir di setiap negara Islam memulai pendistribusian zakat dari pusat lalu meluas hingga mencakup banyak daerah (Qardhawi, 2005). 
Apabila zakat didistribusikan di luar wilayah zakat itu dikumpulkan sedangkan dalam wilayah tersebut masih banyak mustahiq yang membutuhkannya, maka hal itu bertentangan dengan hikmah yang ingin direalisasikan dari adanya kewajiban zakat. Dalam kitab Al-Mughni, dijelaskan bahwa maksud dari adanya zakat adalah menutupi kebutuhan fakir miskin. Oleh karena itu, diutamakan pendistribusian zakat kepada fakir miskin di wilayah zakat dikumpulkan. disepakati bahwasannya pendistribusian zakat dilakukan di mana zakat tersebut dikumpulkan. Apabila ternyata zakat hanya dipergunakan sebagian saja atau tidak sama sekali karena tidak ada lagi dan tidak ditemukan mustahiq yang berhak menerima di daerah tersebut, maka diperbolehkan zakat didistribusikan ke luar daerah, baik dengan menyerahkan penanganannya kepada pemimpin negara atau kepada lembaga zakat pusat (Qardhawi, 2005).

\subsection{Efektivitas Penyaluran Zakat}

Efektivitas menurut Rifa'i dalam Bahri dan Khumaini (2020) dapat diartikan sebagai sebuah keberhasilan suatu aktivitas atau kegiatan dalam mencapai tujuan (sasaran) yang telah ditentukan sebelumnya. Efektivitas penyaluran zakat diukur dengan menggunakan Zakat Core Principles (ZCP).
Penilaian efektivitas penyaluran zakat dengan menggunakan ZCP bertujuan untuk mengetahui bagaimana penyaluran dana zakat yang dikelola lembaga zakat telah memenuhi standar kriteria efektif sesuai dengan acuannya sehingga pengelolaannya dapat dipertanggungjawabkan.

Berdasarkan ZCP, maka rasio yang digunakan adalah Allocation to Collection Ratio (ACR). Rasio ini digunakan untuk mengukur kemampuan sebuah lembaga zakat dalam menyalurkan dana zakatnya dengan cara membagi total dana penyaluran dengan total dana penghimpunan. Penilaian ACR terdiri dari beberapa kategori, dengan rincian: Highly Effective (jika $\mathrm{ACR} \geq 90$ persen), Effective (jika ACR mencapai 70-89 persen), Fairly Effective (jika ACR mencapai 50-69 persen), Below Expectation (jika ACR mencapai 20-49 persen), dan Ineffective (jika $\mathrm{ACR}<20$ persen) (BAZNAS, 2018).

\subsection{ACR (Allocation to Collection Ratio)}

Efektifitas yang digunakan dalam penelitian ini adalah melalui rasio ACR (Allocation to Collection Ratio), yakni merupakan perbandingan antara jumlah zakat yang disalurkan dengan jumlah zakat yang dihimpun. Perhitungan ini sangat penting digunakan sebagai indikator kinerja 
penyaluran zakat lembaga yang ada. Apabila suatu lembaga memiliki nilai ACR 90\%, maka berarti bahwa $90 \%$ zakat yang dihimpun telah disalurkan. Amil menggunakan dana sebanyak 10 persen untuk memenuhi seluruh kegiatan operasionalnya. Hal tersebut memberikan makna bahwa semakin rendah prosentase nilai ACR, menunjukkan semakin lemahnya kemampuan manajemen penyaluran lembaga zakat. Adanya keadaan tersebut, sehingga diperlukan langkah untuk memperbaikinya.

Senada dengan pernyataan tersebut, Beik (2016) juga mengungkapkan bahwa ACR merupakan rasio perbandingan antara proporsi dana zakat yang disalurkan dengan dana zakat yang dihimpun. Adapun lima kategori nilai ACR ini, yaitu kategori highly effective (>90 persen), effective (70 persen 89 persen), fairly effective (50 persen - 69 persen), below expectation (20 persen - 49 persen), dan ineffective ( $<20$ persen).

Menurut Pusat Kajian Strategis Badan Amil Zakat Nasional (2019), rasio ACR dapat dibagi menjadi 4 (empat) jenis yaitu sebagai berikut:

\section{1) Gross Allocation to Collection Ratio}

Rasio gross ACR ini menghitung saldo penghimpunan dan penyaluran ZIS pada suatu periode ditambah dengan saldo dana ZIS yang dari tahun sebelumnya belum dapat disalurkan pada periode berikutnya. Hal ini untuk melihat sejauh mana penyalurannya dana ZIS baik yang terhimpun pada periode yang sama maupun saldo dari periode sebelumnya dikarenakan masih terdapat kewajiban untuk menyalurkan dana yang diperoleh dari periode sebelumnya.

\section{Rumus Gross Allocation Ratio:}

(Penyaluran Dana Zakat + Dana Infak

\begin{tabular}{c} 
Sedekah $)$ \\
\hline (Penghimpunan Dana Zakat + Dana Infak \\
Sedekah $)+\left(\right.$ Saldo Dana Akhir Zakat ${ }_{t-1}+$ \\
Saldo Dana Akhir Infak $\left.{ }_{t-1}\right)$
\end{tabular}

\section{2). Gross Allocation to Collection Ratio}

\section{Non-Amil}

Rasio gross ACR non amil ini menghitung saldo penghimpunan dan penyaluran ZIS pada suatu periode ditambah dengan saldo dana ZIS yang dari tahun sebelumnya belum dapat disalurkan pada periode berikutnya tanpa memasukkan proporsi penyaluran kepada amil. Hal ini untuk melihat sejauh mana penyalurannya dana ZIS baik yang terhimpun pada periode yang sama maupun saldo dari periode sebelumnya kepada 7 golongan ahsnaf yang 
Volua Jurnal Ilmiah Akuntansi Keuangan dan Bisnis

Vol. 1 No. 1 Bulan April - September 2020

lain dikarenakan aktivitas inti dari suatu organisasi pengelola zakat adalah menyalurkan dana ZIS kepada 7 golongan ashnaf selain Amil.

Rumus Gross Allocation Rasio Non-Amil:

(Penyaluran Dana Zakat + Dana Infak Sedekah) - (Bagian amil dari dana zakat + bagian amil dari dana infak)

(Penghimpunan Dana Zakat + Dana Infak Sedekah $)+\left(\right.$ Saldo Dana Akhir Zakat ${ }_{t-1}+$ Saldo Dana Akhir Infak $\left.{ }_{t-1}\right)$ - (Bagian amil dari dana zakat + bagian amil dari dana infak)

\section{3). Net Allocation to Collection Ratio}

Rasio Net ACR ini hanya memperhitungkan penghimpunan dan penyaluran yang dikeluarkan dalam satu periode saja tanpa memperhitungkan sisa saldo dana ZIS dari periode sebelumnya.

Rumus Net Allocation Ratio:

Penyaluran Dana Zakat + Dana Infak

Sedekah

Penghimpunan Dana Zakat + Dana Infak sedekah

\section{4). Net Allocation to Collection Ratios Non-Amil}

Rasio Net ACR ini hanya memperhitungkan penghimpunan dan penyaluran yang dikeluarkan dalam satu periode saja tanpa memperhitungkan sisa saldo dana ZIS dari periode sebelumnya dengan mengeluarkan proporsi penyaluran kepada Amil.

Rumus Net Allocation Ratio Non-Amil:

(Penyaluran Dana Zakat + Dana infak sedekah)

- (bagian amil dari dana zakat + bagian amil dari dana infak)

(penghimpunan Dana Zakat + Dana Infak sedekah ) - (bagian amil dari Dana Zakat + bagian amil dari dana infak)

Interprestasi rentang nilai Net ACR Non Amil dapat ditunjukkan melalui tabel di bawah ini:

\begin{tabular}{|c|c|c|c|c|}
\hline \multicolumn{5}{|c|}{ interpretasi nilai rasio ACR sebagai } \\
berikut: \\
\hline $\mathrm{R}<$ & $45 \%<$ & $60 \%<$ & $75 \%$ & $\mathrm{R}$ \\
$45 \%$ & $\mathrm{R}<$ & $\mathrm{R}<$ & $<\mathrm{R}<$ & $>90 \%$ \\
& $60 \%$ & $75 \%$ & $90 \%$ & \\
\hline Tidak & Kurang & Cukup & & Sangat \\
Efektif & Efektif & Efektif & Efektif & Efektif \\
\hline
\end{tabular}

\section{Metode Penelitian}

Penelitian ini menggunakan metode penggabungan antara metode kualitatif dan kuantitaif. Penelitian kualitatif adalah penelitian yang bermaksud untuk memahami fenomena tentang apa yang dialami oleh subjek penelitian misalnya perilaku, persepsi, motivasi, tindakan, dan lain-lain secara holistik. Pendekatan yang dilakukan adalah dengan cara deskripsi dalam bentuk 
kata-kata dan bahasa, pada suatu konteks khusus yang alamiah dan dengan memanfaatkan berbagai metode alamiah (Kuntjojo, 2009). Sedangkan penelitian kuantitatif adalah suatu proses menemukan pengetahuan yang menggunakan data berupa angka sebagai alat menganalisis keterangan mengenai apa yang ingin diketahui.

Metode kualitatif pada penelitian ini menggunakan pendekatan deskriptif dan studi literatur. Sedangkan metode kuantitatif dengan menggunakan rasio pengukuran Zakat Core Principle. Objek yang digunakan dalam penelitian ini adalah laporan keuangan Yayasan Rumah Zakat tahun 2018.

\section{Hasil Penelitian dan Pembahasan}

\subsection{Hasil Penelitian}

Tumbuhnya Rumah Zakat sebagai LAZNAS terpercaya tidak terlepas dari sejarah panjangnya yang berawal kelompok pengajian Majlis Taklim Ummul Quro sepakat membentuk lembaga sosial yang concern pada bantuan kemanusiaan. 2 Juli 1998 terbentuklah organisasi bernama Dompet Sosial Ummul Quro (DSUQ). DSUQ berubah nama menjadi Rumah Zakat Indonesia, seiring dengan turunnya SK Menteri Agama RI No. 157 pada tanggal 18
Maret 2003 yang mensertifikasi organisasi ini sebagai Lembaga Amil Zakat Nasional.

Pertumbuhan cabang meningkat pesat. Tsunami Aceh yang terjadi 26 Desember 2004 membuka akses Rumah Zakat Indonesia lebih berperan di Sumatra. Cabang-cabang baru pun dibuka: cabang Aceh, Medan, Padang, Palembang, Batam berdiri. Di Jawa, berdiri pula kantor cabang Semarang, ditambah jaringan kantor cabang pembantu di Bekasi, Bogor, Depok, Jakarta Selatan, Cirebon, Solo. Cabang Pekanbaru juga berekspansi dengan memiliki kantor cabang pembantu Duri dan Dumai. Sistem informasi lembaga mulai masuk ke jaringan on line. Mulai transaksi online, absensi on line, dan beberapa software keuangan. Penerimaan donasi meningkat tajam khususnya dari bantuan masyarakat untuk program rehabilitasi pasca tsunami Aceh. Dimulainya pembangunan sistem Teknologi Informasi untuk peningkatan mutu pelayanan. Hampir seluruh kantor cabang telah tersambung secara online. Website www.rumahzakat.org dirilis, menggantikan alamat situs sebelumnya di www.rumahzakat.net. Menguatkan branding lembaga dengan nama Rumah Zakat Indonesia.

Pada Tanggal 5 April 2010, resmi diluncurkan brand baru RUMAH ZAKAT 
Volua Jurnal Ilmiah Akuntansi Keuangan dan Bisnis

Vol. 1 No. 1 Bulan April - September 2020

menggantikan brand sebelumnya RUMAH

ZAKAT INDONESIA. Dengan mengusung

tiga brand value baru: Trusted, Progressive

dan Humanitarian, organisasi ini

menajamkan karakter menuju "World Class

Socio-Religious Non Governance

Organization (NGO)". Sharing Confidence diangkat menjadi positioning. "Dengan keyakinan yang kuat untuk berbagi dan menciptakan keluarga global yang lebih baik, Rumah Zakat berdaya upaya untuk menjadi organisasi terdepan di region yang menjamin program efektif dan berkesinambungan dalam memberdayakan masyarakat untuk mencapai kehidupan yang lebih baik".

Teknik analisis yang digunakan adalah mengacu kepada rasio ACR (Allocation to Collection Ratio). Tahap pertama penulis mengelompokkan akunakun laporan keuangan badan amil Yayasan Rumah zakat yang akan digunakan dan dimasukkan ke dalam rumus perhitungan rasio yang telah ditentukan. laporan keuangan yang digunakan adalah laporan keuangan tahun 2018. Berikut ini adalah nilai masing-masing akun yang telah ditabulasi dari laporan keuangan Yayasan rumah zakat:
Tabel 4.1 Tabulasi Laporan keuangan rumah zakat tahun 2018

\begin{tabular}{|c|c|}
\hline Keterangan & Jumlah \\
\hline Penyaluran dana zakat & 120.193 .117 .257 \\
\hline Dana Infak sedekah & 16.501 .025 .099 \\
\hline penghimpunan dana zakat & 120.580 .750 .711 \\
\hline saldo dana akhir zakat t-1 & 1.628 .443 .431 \\
\hline saldo dana akhir infak t-1 & 14.579 .727 .401 \\
\hline bagain amil dari dana & - \\
zakat & \\
\hline bagian amil dari dana infak & 21.619 .325 .564 \\
\hline
\end{tabular}

Sumber: data diolah oleh peneliti (2020)

Tabel 4.2 Tabulasi Nilai rasio ACR (Allocation to Collection Ratio)

\begin{tabular}{|l|c|}
\hline \multicolumn{1}{|c|}{ Keterangan } & \multicolumn{1}{c|}{$\begin{array}{c}\text { Nilai } \\
\text { ACR }\end{array}$} \\
\hline $\begin{array}{l}\text { Gross Allocation to } \\
\text { Collection Ratio }\end{array}$ & $89,17 \%$ \\
\hline $\begin{array}{l}\text { Gross Allocation to } \\
\text { Collection Ratio Non-Amil }\end{array}$ & $87,40 \%$ \\
\hline $\begin{array}{l}\text { Net Allocation to Collection } \\
\text { Ratio }\end{array}$ & $99,71 \%$ \\
\hline $\begin{array}{l}\text { Net Allocation to Collection } \\
\text { Ratios Non-Amil }\end{array}$ & $99,66 \%$ \\
\hline
\end{tabular}

Sumber: data diolah oleh peneliti (2020)

\subsection{Pembahasan}

\section{Rasio Gross Allocation to Collection}

Ratio digunakan untuk melihat sejauh mana penyaluran dana ZIS baik yang terhimpun pada periode yang sama maupun saldo dari periode sebelumnya dikarenakan masih terdapat kewajiban untuk menyalurkan dana yang diperoleh dari periode sebelumnya. Berdasarkan hasil perhitungan rasio Gross Allocation to Collection Ratio Yayasan Rumah Zakat adalah $89,17 \%$ artinya penyaluran dana ZIS baik yang terhimpun 
pada periode yang sama maupun saldo dari periode sebelumnya penyalurannya sudah dapat dikate gorikan efektif.

\section{Rasio Gross Allocation to Collection}

Ratio Non-Amil digunakan untuk melihat sejauh mana penyalurannya dana ZIS baik yang terhimpun pada periode yang sama maupun saldo dari periode sebelumnya kepada 7 golongan ahsnaf yang lain dikarenakan aktivitas inti dari suatu organisasi pengelola zakat adalah menyalurkan dana ZIS kepada 7 golongan ashnaf selain Amil. Berdasarkan hasil perhitungan Gross Allocation to Collection Ratio Non-Amil Yayasan Rumah Zakat adalah $87,40 \%$ artinya penyaluran zakat selain kepada amil adalah $87,40 \%$ sisanya 12,6\% disalurkan kepada amil.

Rasio Net Allocation to Collection Ratio ini hanya memperhitungkan penghimpunan dan penyaluran yang dikeluarkan dalam satu periode saja tanpa memperhitungkan sisa saldo dana ZIS dari periode sebelumnya. Berdasarkan hasil perhitungan Net Allocation to Collection Ratio Yayasan Rumah Zakat adalah 99,71\% artinya penghimpunan dan penyaluran dana ZIS sangat efektif.

Rasio Net Allocation to Collection Ratios Non-Amil ini hanya memperhitungkan penghimpunan dan penyaluran yang dikeluarkan dalam satu periode saja tanpa memperhitungkan sisa saldo dana ZIS dari periode sebelumnya dengan mengeluarkan proporsi penyaluran kepada Amil. Berdasarkan hasil perhitungan Net Allocation to Collection Ratios NonAmil Yayasan Rumah Zakat adalah 99,66\%, artinya penyaluran dan penghimpunan dana ZIS selain ke amil sebesar 99,66\% dan sisanya ke amil sebesar $0,34 \%$. Hasil rasio Net Allocation to Collection Ratios NonAmil dikategorikan sangat efektif.

\section{Kesimpulan dan Saran}

\subsection{Kesimpulan:}

a. Rasio Gross Allocation to Collection Ratio Yayasan Rumah Zakat adalah 89,17\% Penyaluran dana ZIS baik yang terhimpun pada periode yang sama maupun saldo dari periode sebelumnya penyalurannya sudah dapat dikategorikan efektif.

b. Rasio Gross Allocation to Collection Ratio Non-Amil Yayasan Rumah Zakat adalah $87,40 \%$ yaitu efektif. artinya penyaluran zakat selain kepada amil adalah $87,40 \%$ sisanya $12,6 \%$ disalurkan kepada amil.

c. Rasio Net Allocation to Collection Ratio Yayasan Rumah Zakat adalah 
99,71\% artinya penghimpunan dan penyaluran dana ZIS sangat efektif.

d. Net Allocation to Collection Ratios Non-Amil Yayasan Rumah Zakat adalah 99,66\%, artinya penyaluran dan penghimpunan dana ZIS selain ke amil sebesar $99,66 \%$ dan sisanya sebesar $0,34 \%$ disalurkan ke amil. Hasil rasio Net Allocation to Collection Ratios Non-Amil dikategorikan sangat efektif.

\subsection{Saran}

a. Efektivitas penyaluran dana ZIS sudah efektif tetapi untuk kedepannya diharapkan lebih ditingkatkan lagi hingga mencapai level sangat efektif. Agar kepercayaan masyarakat terhadap rumah zakat semakin kuat.

b. Karena keterbatasan waktu penelitian, diharapkan kepada peniliti selanjutnya agar meneliti untuk rentang waktu yang lebih panjang.

\section{DAFTAR PUSTAKA}

Al-Qur'an Departemen Agama RI.2015. AlQuran Terjemahan.Jakarta: Yayasan Penerjemah Al-qur'an

Bahri, Efri Syamsul Dan Khumaini, Sabik.2020. Analisis Efektivitas Penyaluran Zakat Pada Badan Amil Zakat Nasional. Journal Of Islamic
Economics And Banking Http://Jurnal.Umt.Ac.Id/Index.Php/Ji eb. No 1 Vol 2 Bulan Januari Tahun 2020. Diakses Tgl 31 Januari 2020. Pukul 20:45

BAZNAS, P. (2018). Outlook Zakat Indonesia 2018. Jakarta: Puskas Baznas.

Beik, Irfan Syauqi.2016. TSAQOFIMeningkatkan Efektivitas Penyaluran Zakat. https://www.republika.co.id/berita/ko ran/iqtishodia/16/04/28/o6cbw616tsaqofi-mening katkan-efektivitaspenyaluran-zakat. Diakses Tgl 4 Januari 2020.

Djazuli, Yadi Janwari. 2002. Lembaga lembaga Perekonomian Umat. Jakarta: PT Raja Grafindo Persada.

Kuntjojo. (2009). Metodologi Penelitian. Kediri

Mu'is. Fahrur. 2011. Zakat A-Z Panduan Mudah, Lengkap dan Praktis tentang Zakat. Solo: Tinta Medina.

Pusat Kajian Strategis badan amil zakat nasional .2019.Rasio Keuangan pengelola zakat: teori dan konsep. BAZNAS: Jakarta

Qadratillah, Meity Taqdir,et al. 2011. Kamus Bahasa Indonesia untuk Pelajar. Badan Pengembangan dan Pembinaan Bahasa, Kementrian Pendidikan dan Kebudayaan: Jakarata

Qardhawi, Yusuf.2005. Spektrum Zakat dalam Membangun Ekonomi Kerakyatan. Zikrul Media Intelektual: Jakarta.

Undang-Undang No.23 Tahun 2011 Tentang Pengelolaan Zakat

Zuhri, Saifudin. 2012. Zakat di Era Reformasi (Tata Kelola Baru). Semarang: Fakultas Tarbiyah IAIN Walisongo 